\title{
Structural biology of the Bcl-2 family and its mimicry by viral proteins
}

\author{
M Kvansakul ${ }^{\star, 1}$ and MG Hinds ${ }^{\star, 2,3}$
}

Intrinsic apoptosis in mammals is regulated by protein-protein interactions among the B-cell lymphoma-2 (Bcl-2) family. The sequences, structures and binding specificity between pro-survival Bcl-2 proteins and their pro-apoptotic Bcl-2 homology 3 motif only (BH3-only) protein antagonists are now well understood. In contrast, our understanding of the mode of action of Bax and Bak, the two necessary proteins for apoptosis is incomplete. Bax and Bak are isostructural with pro-survival Bcl-2 proteins and also interact with BH3-only proteins, albeit weakly. Two sites have been identified; the in-groove interaction analogous to the pro-survival BH3-only interaction and a site on the opposite molecular face. Interaction of Bax or Bak with activator BH3-only proteins and mitochondrial membranes triggers a series of ill-defined conformational changes initiating their oligomerization and mitochondrial outer membrane permeabilization. Many actions of the mammalian pro-survival Bcl-2 family are mimicked by viruses. By expressing proteins mimicking mammalian pro-survival Bcl-2 family proteins, viruses neutralize death-inducing members of the Bcl-2 family and evade host cell apoptosis during replication. Remarkably, structural elements are preserved in viral Bcl-2 proteins even though there is in many cases little discernible sequence conservation with their mammalian counterparts. Some viral Bcl-2 proteins are dimeric, but they have distinct structures to those observed for mammalian $\mathrm{Bcl}-2$ proteins. Furthermore, viral $\mathrm{Bcl}-2$ proteins modulate innate immune responses regulated by NF- $\kappa$ B through an interface separate from the canonical BH3-binding groove. Our increasing structural understanding of the viral Bcl-2 proteins is leading to new insights in the cellular Bcl-2 network by exploring potential alternate functional modes in the cellular context. We compare the cellular and viral Bcl-2 proteins and discuss how alterations in their structure, sequence and binding specificity lead to differences in behavior, and together with the intrinsic structural plasticity in the Bcl-2 fold enable exquisite control over critical cellular signaling pathways.

Cell Death and Disease (2013) 4, e909; doi:10.1038/cddis.2013.436; published online 7 November 2013

Subject Category: Cancer

Facts

- Heterodimerization and conformational change of cellular $\mathrm{Bcl}-2$ proteins underpins the initiation and modulation of the intrinsic apoptosis.

- Viral Bcl-2 proteins can adopt different homodimeric configurations that allow modulation of the Bcl-2-mediated pathway as well as $\mathrm{NF}-\kappa \mathrm{B}$ signaling.

- In contrast to cellular pro-survival $\mathrm{Bcl}-2$ proteins, their viral counterparts have lower affinities for their $\mathrm{BH} 3$-only binding partners.

\section{Open Questions}

- The structural basis of full-length Bak/Bax engagement by pro-survival $\mathrm{Bcl}-2$ proteins has yet to be elucidated.
- Does the Bax/Bak oligomeric pore have a defined architecture in the MOM?

- Is there a role for cellular $\mathrm{Bcl}-2$ proteins in $\mathrm{NF}-\kappa \mathrm{B}$ signaling, analogous to that observed for viral $\mathrm{Bcl}-2$ proteins?

- What are the key cellular pro-apoptotic $\mathrm{Bcl}-2$ proteins requiring neutralization during viral infection?

Cues that initiate apoptosis, the programmed elimination of cells no longer required, infected or dangerous to an organism may arise from stimuli external to the cell (extrinsic or death receptor-induced apoptosis) or intracellular (intrinsic, mitochondrial or Bcl-2-regulated apoptosis). ${ }^{1,2}$ The result of activation of either mode of apoptosis is the induction of a proteolytic cascade of cysteine aspartyl proteases (caspases) that dismantles cells before their engulfment by phagocytes and destruction in lysozomes. ${ }^{3}$ The final fate of cells broken

\footnotetext{
${ }^{1}$ La Trobe Institute for Molecular Science, La Trobe University, Bundoora 3086, Victoria, Australia; ${ }^{2}$ School of Chemistry, the University of Melbourne, Parkville 3010, Victoria, Australia and ${ }^{3}$ Bio21 Molecular Science and Biotechnology Institute, the University of Melbourne, Parkville 3010, Victoria, Australia

${ }^{*}$ Corresponding authors: M Kvansakul, La Trobe Institute for Molecular Science, La Trobe University, Bundoora 3086, Victoria, Australia. Tel: +61 394792263 ; E-mail: M.Kvansakul@latrobe.edu.au

or MG Hinds, School of Chemistry and Bio21 Molecular Science and Biotechnology Institute, University of Melbourne, 30 Flemington Road, Parkville 3010, Victoria, Australia. Tel: +61 38344 2502; Fax: +61 39347 5180; E-mail: mhinds@ @unimelb.edu.au

Keywords: apoptosis; $\mathrm{Bcl}-2$; $\mathrm{BH} 3-$ only; protein structure; viral Bcl-2; virus

Abbreviations: Bcl-2, B-cell lymphoma-2; BH, Bcl-2 homology; IDP, intrinsically disordered protein; IDR, intrinsically disordered region; MOM, mitochondrial outer membrane; MOMP, MOM permeabilization; vBcl-2, viral Bcl-2

Received 25.7.13; revised 09.9.13; accepted 02.10.13; Edited by A Oberst
} 
down and packaged during apoptosis is to be recycled through phagocytic clearance. Bcl-2 proteins may also have a part in autophagic cellular destruction, ${ }^{4}$ though the crosstalk between autophagy and apoptosis is not yet well understood ${ }^{5}$ and probably does not have a more general role in programmed cell death. ${ }^{6}$ Molecular mechanisms of apoptotic cell death are highly conserved, and the extrinsic and intrinsic pathways intersect at the mitochondria by direct regulation of the Bcl-2 family.

Approximately 20 proteins define the mammalian B-cell lymphoma-2 (Bcl-2) family and regulate intrinsic apoptosis. ${ }^{2,7}$ This family has been traditionally defined by the presence of a set of short conserved sequences ( $<20$ residues) known as Bcl-2 homology $(\mathrm{BH})$ motifs (also commonly called domains though they are not bona fide discreetly folded compact entities, but rather represent conserved sequence motifs within the $\mathrm{Bcl}-2$ protein). Responding to diverse apoptotic stimuli Bax or Bak, the two key Bcl-2 proteins, initiate cell death by mitochondrial outer membrane permeabilization (MOMP). ${ }^{8}$ Release of cytochrome $c$ and other factors from the mitochondrial intermembrane space, by an as yet ill-defined mechanism of MOMP, initiates the critical caspase cascade. ${ }^{7}$ $\mathrm{Bcl}-2$ proteins either inhibit or activate MOMP and interactions between pro-survival and pro-apoptotic proteins of the family adjudicate cell death. Many of these interactions have been elucidated biochemically and there is now a well-understood pedigree of interactions within this family. ${ }^{9-11}$

Viruses have evolved multiple strategies to subvert host cell apoptosis in response to cellular infection. ${ }^{12}$ Viral interference with apoptotic signaling can occur at multiple control points, such as inhibition of death receptor activation (extrinsic apoptosis), ${ }^{13}$ direct caspase inhibition, ${ }^{14}$ or by mimicking pro-survival $\mathrm{Bcl}-2$ family action (intrinsic apoptosis) ${ }^{15}$ (Figure 1). Here we discuss recently determined structures in the mammalian Bcl-2 family and compare mammalian and viral Bcl-2 proteins and viral Bcl-2 mimicry. Not all features of mammalian $\mathrm{Bcl}-2$ structure and function need be retained by viral Bcl-2 proteins, as the essential goal is to maintain host cell viability while permitting viral replication to proceed in the absence of apoptosis. Indeed, there are remarkable similarities between some viral $\mathrm{Bcl}-2$ proteins and their mammalian counterparts. There are also perplexing differences between the dimers observed in the viral Bcl-2 family from those of their mammalian equivalents.

\section{BH Motifs-a Distinguishing Feature of the Bcl-2 Family?}

Sequence analysis of the $\mathrm{Bcl}-2$ family identified conserved regions, ${ }^{16}$ later named as $\mathrm{BH}$ motifs. $\mathrm{BH} 1$ and $\mathrm{BH} 2$ motifs were initially identified in $\mathrm{Bcl}-2^{17}$ and the $\mathrm{BH} 3$ motif in Bak, ${ }^{18}$ with a fourth poorly conserved ${ }^{19}$ motif, $\mathrm{BH} 4$, proposed in the $\mathrm{N}$-terminal region of $\mathrm{Bcl}-2$ and the closely related $\mathrm{Bcl}-\mathrm{x}_{\mathrm{L}}$ and $\mathrm{Bcl}-\mathrm{w} .{ }^{16,20}$ Searches for $\mathrm{BH}$ motifs in numerous genomes led to the identification of many $\mathrm{Bcl}-2$ family members ${ }^{21,22}$ and potential, though experimentally unproven, members. ${ }^{23}$ The mammalian Bcl-2 family can be classified into the multi-motif Bcl-2 proteins that bear multiple $\mathrm{BH}$ motifs with pro-survival $\left(\mathrm{Bcl}-2, \mathrm{Bcl}-\mathrm{x}_{\mathrm{L}}\right.$, Bcl-w, Mcl-1, A1, Bcl-B) and pro-apoptotic (Bax, Bak) activity. The pro-apoptotic BH3-only proteins (Bim, Bad, Bmf, tBid, Noxa, Bik, Puma, Hrk) bear only a single motif, a BH3.

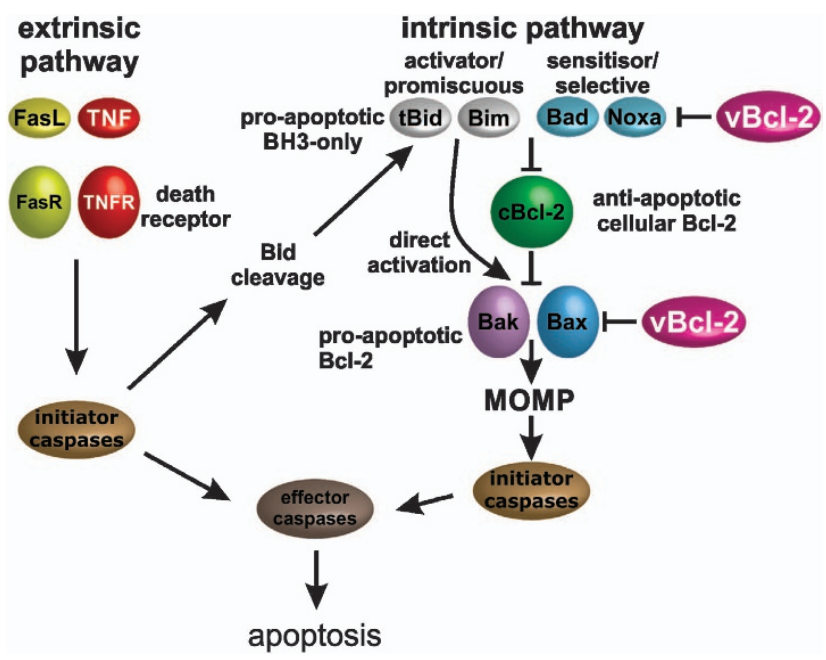

Figure 1 Points of intervention of viral Bcl-2 proteins in mammalian Bcl-2regulated apoptosis. Shown is a simplified schematic view of apoptosis induction in mammalian cells and its inhibition by pro-survival viral $\mathrm{Bcl}-2$ (vBcl-2) proteins. Apoptosis may be initiated by activation of cell surface receptors (extrinsic apoptosis or death receptor-initiated apoptosis ${ }^{7}$ ) or by intracellular mechanisms ('intrinsic' or mitochondrial pathway). In either case, a proteolytic cascade of caspases is initiated that destroys the cell. A network of interactions between Bcl-2 proteins controls mitochondrial membrane integrity. BH3-only proteins may either inhibit pro-survival proteins or activate the two key Bcl-2 family members, Bax and Bak, to disrupt the mitochondrial outer membrane and release caspase-activating factors. Viral Bcl-2 proteins bind $\mathrm{Bax}$ or Bak or $\mathrm{BH} 3-o n l y$ proteins to prevent apoptosis induction. cBcl-2, cellular Bcl-2

The presence of a $\mathrm{BH} 3$ motif defines all pro-apoptotic $\mathrm{Bcl}-2$ proteins, ${ }^{24}$ although it may or may not be present in pro-survival proteins. Analysis of $\mathrm{BH}$-sequence proteins delineates a motif that bears four hydrophobic residues spanning $\sim 2$ heptads. One of these residues is an almost invariant leucine, separated by three residues from a Xaa-Asp dyad, where Xaa is Gly, Ala or Ser, and is a feature that distinguishes $\mathrm{BH} 3$ motifs. ${ }^{9,25}$ The $\mathrm{BH} 4$ motif appears to be less defining, early classifications suggested that this motif was only present in certain pro-survival proteins but not in the pro-apoptotic members. ${ }^{26}$ However, more recently, the $\mathrm{BH} 4$ was re-defined as a conserved structure-sequence motif, $\phi 1-\phi 2-\mathrm{X}-\mathrm{X}-\phi 3-\phi 4$, found in all folded $\mathrm{Bcl}-2$ proteins, where $\mathrm{X}$ is any amino acid, $\phi 1, \phi 2$ and $\phi 4$ are aliphatic residues and $\phi 3$ an aromatic residue. ${ }^{27}$ Being present on both pro-survival, including viral $\mathrm{Bcl}-2$ homologs, and pro-apoptotic Bcl-2 proteins, it cannot distinguish them and as an isolated parameter does not identify $\mathrm{Bcl}-2$ proteins. ${ }^{28}$ Not all $\mathrm{BH}$ motifs are present within a given $\mathrm{Bcl}-2$ protein and several viral $\mathrm{Bcl}-2$ fold proteins lack obvious $\mathrm{BH}$ motifs (e.g., M11L, $\mathrm{N} 1 \mathrm{~L}, \mathrm{~F} 1 \mathrm{~L})^{27,29-32}$ altogether indicating $\mathrm{BH}$ motifs are not an essential feature for $\mathrm{Bcl}-2$-fold proteins. As structures of more distantly related $\mathrm{Bcl}-2$ family proteins emerge, our understanding of the sequence and structural diversity permitted in the $\mathrm{Bcl}-2$ family will be refined.

\section{An $\alpha$-Helical Fold Provides a Binding Site and Defines Multi-Motif Bcl-2 Proteins}

Structural studies have defined the Bcl-2 family interactions at atomic resolution. ${ }^{33-36}$ The structures of the multi-motif 
proteins are highly homologous $\alpha$-helical bundles. Figure 2 shows the basic fold, as exemplified by $\mathrm{Bcl}-\mathrm{x}_{\mathrm{L}}$, shared by both the pro-apoptotic and anti-apoptotic multi-motif proteins. Structures of $\mathrm{BH} 3$ complexes of the pro-survival proteins show that the $\mathrm{BH} 3$ ligand binds as an amphipathic helix in a hydrophobic groove formed from residues in the $\mathrm{BH} 1, \mathrm{BH} 2$ and $\mathrm{BH} 3$ motifs (or their structural equivalents where the $\mathrm{BH}$ sequence motif is absent) of the pro-survival protein. ${ }^{35,37}$ The majority of intermolecular contact residues reside in a 13-residue segment of the $\mathrm{BH} 3$ motif, including the 4 hydrophobic residues, ${ }^{25}$ and both molecules contribute almost equally to the binding surface $\left(\sim 1000 \AA^{2}\right.$ buried surface each). Although the topology of the pro-survival proteins is nearly identical, each protein has a different specificity for $\mathrm{BH} 3$ targets (summarized in Table 1).

The distinction between the $\mathrm{BH} 3$-only and the multi-motif proteins is not only in their biological activity and sequences but also in their structures. The BH3-only proteins are intrinsically disordered proteins (IDPs) ${ }^{38,39}$ or become disordered after processing. ${ }^{40}$ In contrast, the multi-motif proteins are folded entities, but bear intrinsically disordered regions (IDRs). ${ }^{39}$ The sequence and structural differences between the multi-motif and $\mathrm{BH} 3$-only proteins lead to the conclusion that they are separate phylogenetic classes. ${ }^{41}$

Structures of full-length $\mathrm{Bax}^{42}$ and $\mathrm{Bid}^{43,44}$ have been determined, but generally structural investigations have focused on 'transmembrane' (TM)-region truncated proteins due to their better expression and solubility properties. Bid, the only $\mathrm{BH} 3-$ only protein with a well-defined structure, has a hydrophobic core structure similar to the Bcl-2 fold. ${ }^{43,44}$ Activation of Bid by proteolytic cleavage in the $\alpha 1-\alpha 2$ loop by multiple proteases, including caspase-8, Granzyme B, calpains and cathepsins, ${ }^{45}$ to form truncated Bid (tBid) containing the $\mathrm{BH} 3$ region leaves it stably folded. ${ }^{44}$ Like Bak and $\mathrm{Bax}$, the Bid $\mathrm{BH} 3$ motif is released for binding in the presence of a membrane environment. ${ }^{46}$ In Bax, the C-terminal $\alpha$-helix occupies a similar position to the BH3-only binding site on pro-survival proteins and blocks the groove. $\mathrm{Bcl}-\mathrm{w}^{47,48}$ has a similar structure to Bax and biochemical and kinetic evidence is consistent with the C-terminal residues of other $\mathrm{Bcl}-2$ proteins, such as $\mathrm{Bcl}-\mathrm{x}_{\mathrm{L}}$ and $\mathrm{Mcl}-1$, also occupying the groove. ${ }^{4,49}$ These findings indicate that the binding groove is hindered or occupied in the multi-motif proteins.

Two distinct roles are performed by $\mathrm{BH} 3$-motif residues: one as a ligand, the other as part of the receptor site groove, in each case different atomic interactions are observed for the $\mathrm{BH}$. This $\mathrm{BH} 3$-in-groove interaction, where the groove is formed by helices $\alpha 2-\alpha 5$ (Figure 2 ) and occupied by the $\mathrm{BH} 3$ motif is a key mechanistic aspect of $\mathrm{Bcl}$-2-regulated apoptosis and one that viral $\mathrm{Bcl}-2$ proteins mimic to prevent cell death initiation.

\section{Bcl-2 Proteins BH3-Ligand Specificity}

Investigation of the affinity and specificity of interactions between $\mathrm{Bcl}-2$ proteins ${ }^{9-11}$ (Table 1) led to proposals for the mechanisms of apoptosis initiation. Two main mechanisms have been hypothesized. The 'indirect activation'
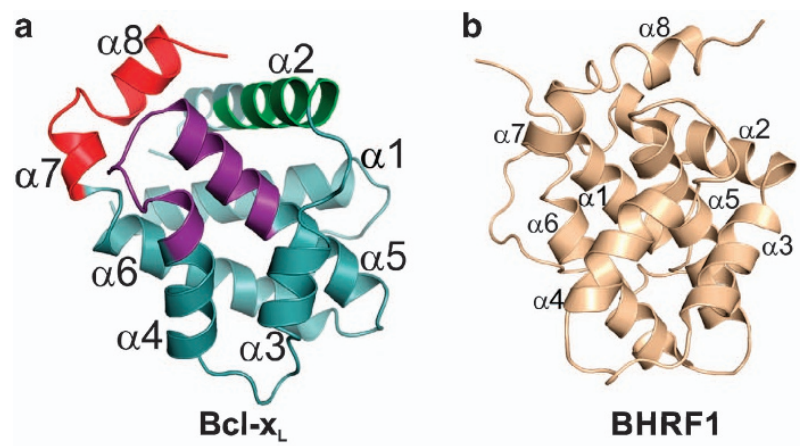

BHRF1

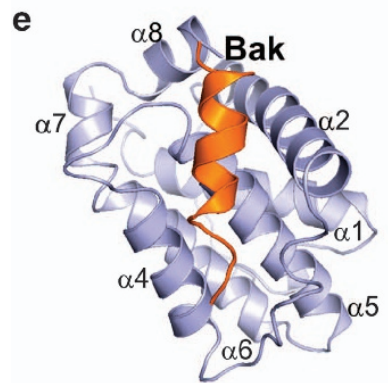

Bcl- $\mathrm{X}_{\mathrm{L}}:$ Bak BH3

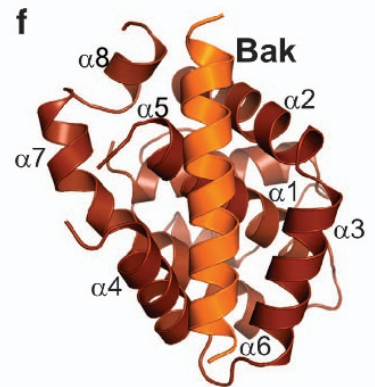

BHRF1:Bak BH3
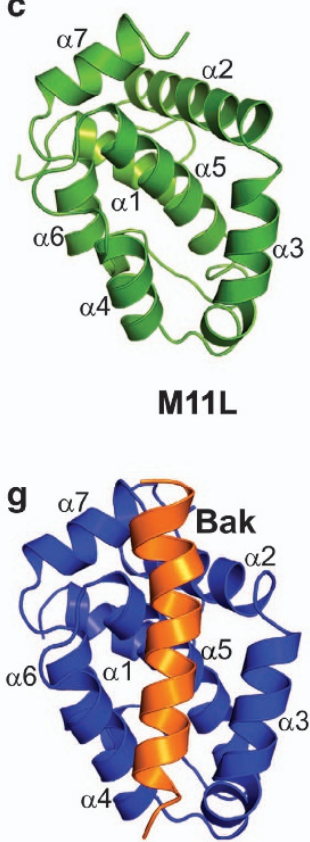

M11L:Bak BH3 d

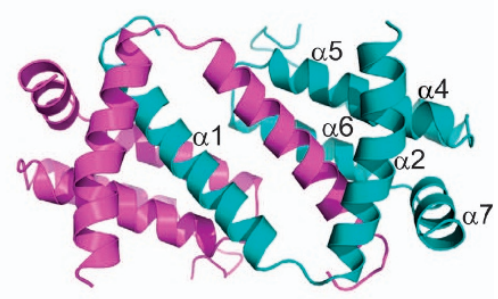

F1L

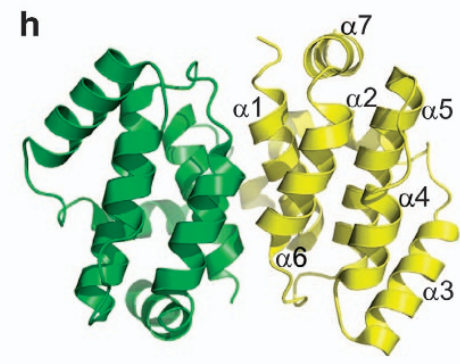

N1L

Figure 2 Structural comparison of human and viral Bcl-2 proteins and their complexes with Bak BH3 peptides. (a) Human Bcl- $\mathrm{x}_{\mathrm{L}}$ (pdb accession code: 1MAZ) with the BHmotifs colored BH1 purple; BH2, red; BH3, green. (b) Epstein-Barr virus BHRF1 (1Q59), (c) Myxoma virus M11L (2BJX), (d) Vaccinia virus F1L (2VTY), (e) Bcl- $x_{L}: B a k$ (1BXL), (f) BHRF1:Bak (2XPX), (g) M11L:Bak (2JBY), (h) Vaccinia virus N1L (2UXE). The Bak BH3 peptide is shown in orange. Structures were aligned on Bcl- $\mathrm{X}_{\mathrm{L}}$ in a. Protomers of the F1L and N1L dimers are depicted in different colors 
Table 1 Summary of $\mathrm{BH} 3$ motif affinities for $\mathrm{Bcl}-2$ proteins

\begin{tabular}{|c|c|c|c|c|c|c|c|c|c|c|c|}
\hline \multirow[t]{2}{*}{ Pro-death } & \multicolumn{11}{|c|}{ Pro-survival } \\
\hline & SPPV14 & M11L & F1L & $\mathrm{BHRF}^{\mathrm{a}}$ & $\mathrm{KsBcl}-2^{\mathrm{b}}$ & $N 1 L^{b *}$ & Bcl-2 & Bcl-w & Bcl-x & Mcl-1 & $A 1^{a}$ \\
\hline Bad & $>2000$ & $>1000$ & NB & $>2000$ & $>1000$ & $>1000$ & 16 & 30 & 5.3 & $>100000$ & 15000 \\
\hline Bid & $341 \pm 16$ & 100 & NB & 109 & 112 & 152 & 6800 & 40 & 82 & 2100 & 1 \\
\hline Bik & $>2000$ & $>1000$ & NB & $>2000$ & $>1000$ & $\mathrm{n} / \mathrm{a}$ & 850 & 12 & 43 & 1700 & 58 \\
\hline Bim & $26 \pm 4$ & 5 & 250 & 18 & 29 & 72 & 2.6 & 4.3 & 4.6 & 2.4 & 1 \\
\hline $\mathrm{Bmf}$ & $67 \pm 6$ & 100 & NB & $>2000$ & $>1000$ & $\mathrm{n} / \mathrm{a}$ & 3 & 9.8 & 9.7 & 1100 & 180 \\
\hline Hrk & $63 \pm 6$ & $>1000$ & NB & $>1000$ & $>1000$ & $\mathrm{n} / \mathrm{a}$ & 320 & 49 & 3.7 & 370 & 46 \\
\hline Noxa & $>2000$ & $>1000$ & NB & $>2000$ & $>1000$ & $\mathrm{n} / \mathrm{a}$ & $>100000$ & $>100000$ & $>100000$ & 24 & 20 \\
\hline Puma & $65 \pm 1$ & $>1000$ & NB & 70 & 69 & $\mathrm{n} / \mathrm{a}$ & 3.3 & 5.1 & 6.3 & 5 & 1 \\
\hline Bak & $46 \pm 3$ & 50 & 4300 & 150 & $<50$ & 71 & $>1000$ & 500 & 50 & 10 & 3 \\
\hline Bax & $32 \pm 5$ & 75 & 1850 & 1400 & 980 & $\mathrm{n} / \mathrm{a}$ & 100 & 58 & 130 & 12 & $\mathrm{n} / \mathrm{a}$ \\
\hline
\end{tabular}

${ }^{\mathrm{a}}$ Indicates affinities determined by isothermal calorimetry

${ }^{b}$ Indicates affinities determined by florescence polarization

Interactions were determined using SPR methods except where stated. Sources: SPPV14, ${ }^{115} \mathrm{M} 11 \mathrm{~L},{ }^{31} \mathrm{~F} 1 \mathrm{~L},{ }^{27} \mathrm{BHRF} 1,{ }^{107} \mathrm{KsBcl}-2,{ }^{132} \mathrm{~N} 1 \mathrm{~L},{ }^{30} \mathrm{Bcl}-2,{ }^{9,133,134}$ $\mathrm{Bcl}-\mathrm{w},{ }^{9,133,134} \mathrm{Bcl}-\mathrm{x}_{\mathrm{L}}{ }^{9,133,134} \mathrm{Mcl}-1,{ }^{9} \mathrm{~A} 1^{135}$

or 'displacement' model poses that the BH3-only proteins release Bax and Bak from regulation by the pro-survival proteins to initiate MOMP. Whereas the 'direct activation' mechanism proposes two roles for BH3-only proteins: they may act either as 'sensitizers' (Bad, Bmf, Noxa, Hrk, Bik) that interact only with pro-survival proteins or as 'activators' (Bim, Puma, Bid) that interact with pro-survival Bcl-2 proteins and with $\mathrm{Bax}$ and $\mathrm{Bak}^{50}$ (Figure 1). The sensitizer BH3-only proteins sequester the pro-survival proteins preventing interaction with Bax or Bak, leaving them to interact with the activator BH3-only proteins to induce the conformational changes necessary for MOMP. Composite mechanisms have been proposed and the evidence recently reviewed. ${ }^{51} \mathrm{Bim}$ is the universal pro-survival Bcl-2 family antagonist, ${ }^{37}$ whereas other BH3-only family members are more selective and the combination of $\mathrm{Mcl}-1$ and $\mathrm{Bcl}-\mathrm{x}_{\mathrm{L}}$ potentially inhibits all $\mathrm{BH}$ only initiated intrinsic apoptotic pathways. ${ }^{37}$

\section{Things Change at the Membrane}

The least well-understood aspect of Bcl-2 family proteinmediated apoptosis is their interactions at intracellular (mitochondrial, endoplasmic reticulum, golgi and nuclear envelope) membrane surfaces. Many $\mathrm{Bcl}-2$ proteins bear a hydrophobic C-terminal TM sequence, frequently assumed to be helical, for membrane anchorage. Some are constitutively membrane bound (Bak, Bok), whereas others (Bax, Bcl- $\mathrm{x}_{\mathrm{L}}$, $\mathrm{Bcl}-\mathrm{w}, \mathrm{Mcl}-1, \mathrm{~A} 1)$ are partitioned between the membrane and the cytosol and become integrated subsequent to apoptotic stimulus. $^{51,52}$ Like Bim, Noxa, Puma and Bmf, tBid is also found to be membrane associated, though Bad is not. ${ }^{53}$ Most $\mathrm{Bcl}-2$ proteins are targeted to the $\mathrm{MOM}$ but $\mathrm{Bok}^{54}$ and $\mathrm{Bik}^{53}$ locate to the endoplasmic reticulum.

Pro-survival proteins appear to require their TM regions for full pro-survival activity ${ }^{47}$ and recent evidence shows the TM region of $\mathrm{Bcl}-\mathrm{x}_{\mathrm{L}}$ has a role in transferring Bax between the MOM and cytosol. ${ }^{55}$ Before apoptotic stimuli, Bax exists in equilibrium between the cytosol and the MOM and is shuttled between them by $\mathrm{Bcl}-\mathrm{x}_{\mathrm{L}}$ in a process dependent on the $\mathrm{BH} 3$ motif of Bax, a competent BH3-binding groove of Bcl- $x_{L}$ and the $\mathrm{TM}$ region of $\mathrm{Bcl}-\mathrm{x}_{\mathrm{L}},{ }^{55,56}$ but structural details are not available. Other evidence suggests certain $\mathrm{BH} 3$-only proteins directly bind $\mathrm{Bax}$ and $\mathrm{Bak}^{57-61}$ and in the case of Bax results in membrane integration. Some viral Bcl-2 homologs also bear a hydrophobic TM region, suggesting that they too act at the MOM. ${ }^{62,63}$ How pro-apoptotic Bax and Bak affect MOMP remains uncertain. A 'hit and run mechanism,59,64,65 has been proposed based on a weak interaction with a $\mathrm{BH} 3$-only protein inducing a poorly defined and structurally uncharacterized membrane insertion transition. Although biochemical evidence shows the $\mathrm{BH} 3$ motif of Bax (or Bak) is necessary for interaction with pro-survival proteins, currently there is no high-resolution structural data available on any complexes of full-length Bax/Bak: pro-survival Bcl-2 proteins. Further structures will be required to answer this question.

\section{Bcl-2 Proteins Dimerize}

Heterodimerization of $\mathrm{Bak}$ and $\mathrm{Bax}^{66}$ with pro-survival proteins requires a conformational change in one or both partners, ${ }^{67}$ as the key residues in the interacting $\mathrm{BH} 3$ motifs are buried in monomeric Bax and Bak. ${ }^{42,68}$ Early in the exploration of the Bcl-2 family, it was noted that Bax:Bcl-2 dimers form in the presence of non-ionic surfactants (detergents) ${ }^{69}$ and the affinity was recently measured in the presence of the surfactant Brij-35 $\left(K_{\mathrm{d}} \sim 36 \mathrm{nM}\right) .{ }^{70}$ Given that the core of the Bcl-2 fold largely comprises of hydrophobic interactions, it is not surprising that surfactants have an effect on the structure. Bcl- $x_{\mathrm{L}}$ in dodecylphosphocholine micelles forms a molten globule retaining secondary structure but not a tertiary fold. ${ }^{71}$ Conformational change of the $\mathrm{Bcl}-2$ proteins in the membrane is a major feature of their action, ${ }^{72}$ and changes have been observed for Bax and Bak through the use of antibodies specific for epitopes that are not exposed before membrane interaction. ${ }^{73,74}$

In addition to heterodimerization, both pro-survival and pro-apoptotic proteins can homodimerize. Under the influence of heat, organic solvents, $\mathrm{pH}$ or surfactants, $\mathrm{BCl}-\mathrm{x}_{\mathrm{L}}$ dimerizes $^{75-78}$ to form an extended structure capable of binding $\mathrm{BH} 3$ peptides $^{75,78}$ (Figure 3a). An $\alpha 1$ helix swapped dimer of $\mathrm{Bcl}-\mathrm{x}_{\mathrm{L}}$ retaining an ability to bind $\mathrm{BH} 3$ ligands has also been observed (Figure $3 b) .{ }^{79}$ Higher order oligomers of $\mathrm{Bcl}-\mathrm{x}_{\mathrm{L}}$ can 

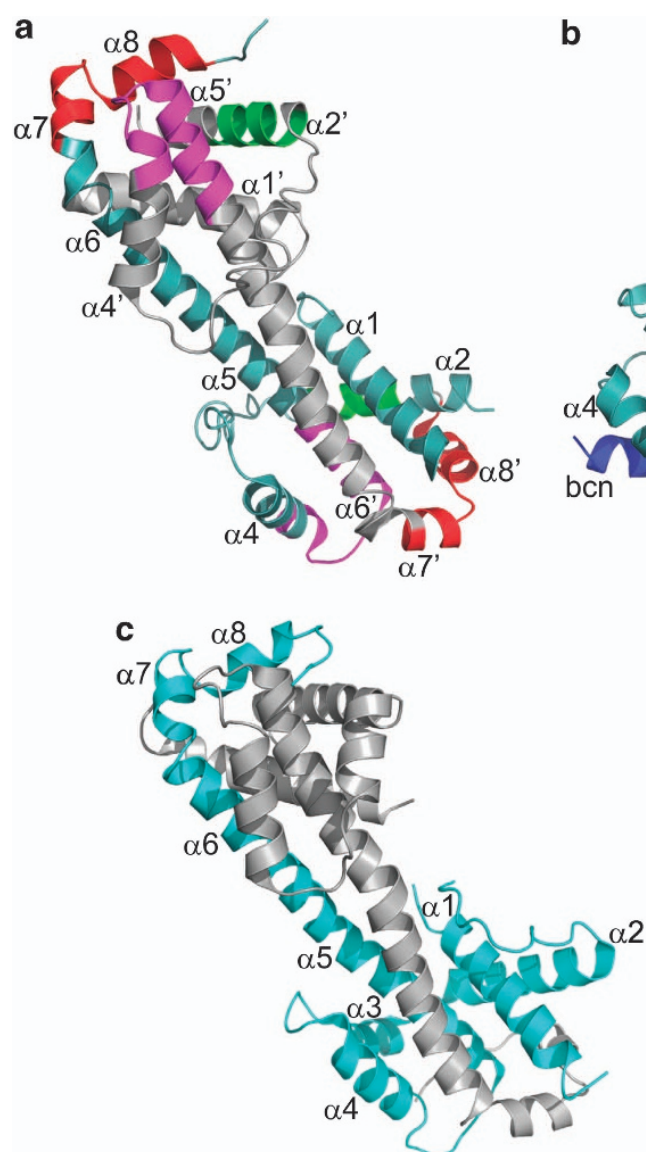

b

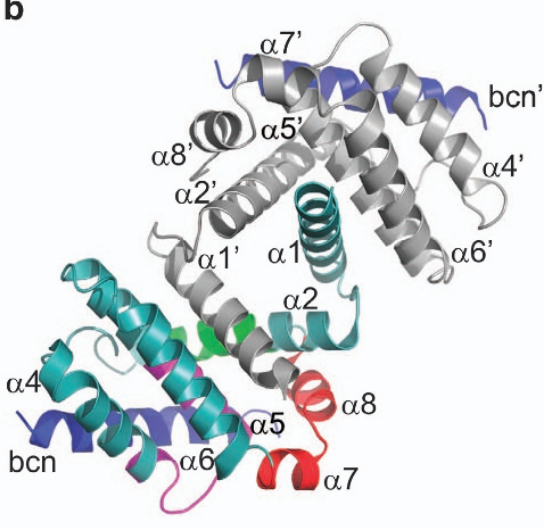

d

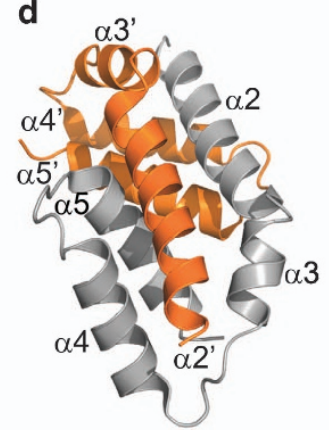

Figure 3 Structures of Bcl-2 dimers. Dimers may be induced by treatment with heat, $\mathrm{pH}$, surfactant or BH3-ligand. (a and $\mathbf{b}) \mathrm{Bcl}-\mathrm{x}_{\mathrm{L}}$ dimers; (c and d) Bax dimers. (a) Bcl- $\mathrm{x}_{\mathrm{L}}$ dimer (2B48). The BH motifs are indicated in color as Figure 1 and the helices indicated with the alternate protomer helices denoted with a prime $\left({ }^{\prime}\right)(\mathbf{b})$ Beclin-1: Bcl- $\mathrm{x}_{\mathrm{L}}$ heterotetramer (2P1L). (c) Octylmaltoside-induced Bax dimer (4BD7) (c) CHAPS-induced alternate dimeric Bax core (4BDU) that contains only the central helices $(\alpha 2-\alpha 5)$ of Bax and lacks both N-terminal residues and the C-terminal TM region. For clarity, the GFP-fusion tag on each chain is not shown. BH motifs have been colored as in Figure 1 . The structures depicted in $\mathbf{a}$ and $\mathbf{c}$ have been structurally aligned with $B c l-x_{L}$ in the same orientation as Figure 1 and the $B c l-x_{L}$ dimer in $\mathbf{b}$ was aligned over helices $\alpha 5-\alpha 8$ on the structure in a

be formed and there appear to be differences between dimers formed using surfactant and $\mathrm{pH}$, the acid-formed dimers bind $\mathrm{BH} 3$ peptides, whereas surfactant-induced dimer did not, though structural details are lacking. ${ }^{77}$ A TM-truncated Bcl-w dimerizes on crystallization, forming a structurally distinct dimer to that of surfactant-induced $\mathrm{Bcl}-\mathrm{x}_{\mathrm{L}}$ with reduced ability to bind $\mathrm{BH} 3$ peptides. ${ }^{80}$ Surfactant treatment of Bax followed by dilution or removal of surfactants gives a surfactant-free dimer with a similar structure to surfactant-induced $\mathrm{Bcl}-\mathrm{x}_{\mathrm{L}}$ dimer, where the central $\alpha 5$ and $\alpha 6$ helices form a single contiguous helix ${ }^{61}$ (Figure 3c). A truncated GFP-tagged Bax retaining only the central $\alpha 2-\alpha 5$ region forms a dimer with a different structure in the absence of surfactant (Figure 3d). Bak has also been reported to dimerize before MOMP. ${ }^{81}$ The functional role, if any, of $\mathrm{Bcl}-2$ protein homodimerization remains unclear, and kinetically pore formation appears to be dependent on monomeric Bax. ${ }^{82}$

Although the multi-motif $\mathrm{Bcl}-2$ monomers are topologically near-identical, the dimers are not, having different architecture depending on the protein and how dimerization was induced (Figure 3). The interaction of proteins with crystallization co-solvents ${ }^{83}$ or surfactants ${ }^{84}$ is complex and surfactant-generated forms may be artifacts of their preparation. ${ }^{85}$ Co-solvents such as methylpentanediol or isopropanol employed in $\mathrm{Bax}^{61}$ and $\mathrm{Bcl}-\mathrm{x}_{\mathrm{L}}{ }^{78}$ dimer crystallization, respectively, may contribute to dimer formation. In contrast to the mammalian counterparts, some viral Bcl-2 proteins appear to be constitutive dimers and have architectures structurally unique to those observed for mammalian proteins (Figures 2 and 3 ).

\section{Alternate Functions for $\mathrm{Bcl}-2$ Proteins?}

Although the main protagonists of the Bcl-2 family now have well-understood roles in apoptosis signaling, even if the exact details of MOMP are not understood, others are less well characterized. This includes $\mathrm{Bcl}-2$ proteins such as $\mathrm{A} 1,{ }^{86}$ Bcl-B ${ }^{37}$ and Bok. ${ }^{54}$ Structurally Boo, the mouse homolog of human Bcl-B (Bcl-2L10), has a Bcl-2 fold ${ }^{87}$ but only binds the known $\mathrm{BH} 3$-only proteins with very weak affinity, ${ }^{87,88}$ suggesting that the human and mouse homologs have diverged functionally. The main difference between Bcl-B and other multi-motif proteins is the presence of an unstructured loop between helices $\alpha 5$ and $\alpha 6^{37}$ shown to be important for regulating its protein levels in cells through ubiquitylation and proteasomal degradation. ${ }^{89}$ 
$\mathrm{Bcl}-2$ proteins may modulate biochemical pathways other than mitochondria-regulated apoptosis. ${ }^{90} \mathrm{Bcl}-\mathrm{x}_{\mathrm{L}}, \mathrm{Bcl}-2$ and Bax interact weakly with the tumor repressor and transcription factor p53. ${ }^{78,91-93}$ NMR studies have shown weak specific interaction between $\mathrm{p} 53$ and $\mathrm{Bcl}-\mathrm{x}_{\mathrm{L}}{ }^{91}$ with a $K_{\mathrm{d}}$ of $370 \mathrm{nM}^{78}$ that is released on Puma binding $\mathrm{Bcl}-\mathrm{x}_{\mathrm{L}}$ in the groove, ${ }^{78}$ providing a potential allosteric mechanism for p53 activation of apoptosis. Bcl-2 family proteins may be involved in regulating mitochondrial remodeling through fusion and fission. ${ }^{94,95}$ It has been proposed that $\mathrm{BCl}-\mathrm{x}_{\mathrm{L}}$ regulates autophagy through interaction with Beclin-1 in a BH3-like interaction $\left(K_{d} \sim 2 \mu \mathrm{M}\right){ }^{79}$ Other potential pathways regulated include energy metabolism $^{41}$ and cell cycle progression, ${ }^{96}$ but details are yet to emerge on interactions and structures. At present, the molecular details of these processes are not firmly established, with many likely to be indirect effects.

\section{Viral Bcl-2 Proteins: Keeping Cells Alive when Hosting a Pathogen}

Molecular mimicry through expression of sequence, structural and functional orthologs of $\mathrm{Bcl}-2$ proteins is an important survival strategy of viruses. ${ }^{97}$ The significance of successful subversion of host cell apoptosis has been demonstrated by construction of deletion mutants for several viruses. Adenovirus, ${ }^{98}$ murine cytomegalovirus, ${ }^{99-101}$ Epstein-Barr virus (EBV), ${ }^{102} \gamma$-herpesvirus, ${ }^{103}$ myxomavirus ${ }^{104}$ and vaccinia virus ${ }^{63}$ trigger apoptosis during infection in the absence of functional viral $\mathrm{Bcl}-2$ proteins. By retaining key structural, but not necessarily sequence features, viral Bcl-2 homologs can inhibit both BH3-only and Bax-like death signals. Readily identifiable viral $\mathrm{Bcl}-2$-like proteins include those found in adenovirus (vBcl-2), ${ }^{105}$ Kaposi sarcoma-associated herpesvirus (KS-Bcl-2), ${ }^{106}$ Epstein-Barr virus (BHRF1), ${ }^{107,108}$ murine $\gamma$-herpesvirus 68 ( $\gamma \mathrm{HV} 68-\mathrm{vBcl}-2){ }^{109}$ herpesvirus saimiri ORF16 ${ }^{110}$ and the recently identified FPV039 from Fowlpox virus, ${ }^{111}$ CNPV058 in canarypox virus ${ }^{112}$ and vNR13, a Bcl-B homolog from avian $\alpha$-herpesvirus. ${ }^{113}$ However, in general, the sequence divergence of $\mathrm{vBcl}-2$ proteins from recognized $\mathrm{Bcl}-2$ proteins has made them difficult to identify by sequence comparison alone. Structures of these vBcl-2 molecules show they are highly similar to mammalian family members. KS-Bcl- $2^{106}$ and $\mathrm{BHRF} 1^{107,108}$ adopt $\mathrm{Bcl}-2$ folds comprising 8 alpha helices and have a TM region indicating that membrane interaction and perhaps interactions in the membrane are necessary for their activity.

More recently, a number of viral Bcl-2 members were identified in pox viruses that, while displaying virtually no sequence identity with mammalian Bcl-2 members adopt a $\mathrm{Bcl}-2$ fold. These include myxoma virus $\mathrm{M} 11 \mathrm{~L}^{31,32}$ and vaccinia virus $\mathrm{F}_{1 \mathrm{~L}}{ }^{27}$ and $\mathrm{N} 1 \mathrm{~L} .^{29,30}$ These three proteins comprise only seven alpha helices, with helix 7 (numbering based on the structure of $\mathrm{Bcl}-\mathrm{x}_{\mathrm{L}}$; Figure 2) being absent. Solving the structures of $\mathrm{N} 1 \mathrm{~L}$ and $\mathrm{F} 1 \mathrm{~L}$ demonstrated the considerable structural diversity to the Bcl-2 fold. N1L and F1L adopt dimeric configurations; with F1L forming a domainswapped dimer mediated by an exchange of $\alpha 1$ helices between two F1L protomers. Intriguingly, the topology of the $\mathrm{F} 1 \mathrm{~L}$ dimer is reminiscent of the $\mathrm{Bcl}-\mathrm{x}_{\mathrm{L}}$ :Beclin-1 $\mathrm{BH} 3$ domainswapped dimer observed by Oberstein et al., ${ }^{79}$ where truncating the $\alpha 1-\alpha 2$ loop results in helix $\alpha 1$ no longer being accommodated within the $\mathrm{Bcl}-2$ fold but located in a neighboring protomer. In contrast, N1L forms a dimer by association of two independently folded N1L chains. ${ }^{29,30}$ Lacking a TM region, N1L has a cytosolic location ${ }^{114}$ and no mammalian $\mathrm{Bcl}-2$ protein has been shown to associate in a similar configuration (Figures 2 and 3 ).

Biochemical interaction studies revealed significant variations in the ligand-binding profile of $\mathrm{vBcl}-2$ proteins with respect to the range and nature of their ligands as well as their affinities. Vaccinia virus F1L has been shown to engage Bim, Bak and Bax only and with moderate affinities. ${ }^{27}$ In contrast, SPPV14 interacts with several BH3-only proteins (Bim, Bid, Bmf, Hrk and Puma) as well as Bak and Bax ${ }^{115}$ at considerably higher affinities (Table 1). In the case of vaccinia virus, expression levels of $\mathrm{F} 1 \mathrm{~L}$ are high and driven by a strong early/late latency promoter. All vbcl-2 are single genes without splice sites and there is some level of conservation of the location within the genome in the pox viruses, indicating common progenitors. Another contrast with the mammalian $\mathrm{Bcl}-2$ family is that no inhibitors of $\mathrm{Mcl}-1$-specific binders (Noxa) have been found. Immunoprecipitation analysis has indicated N1L associates with Bad and ORFV125 binds Noxa, but no affinities have been determined with purified proteins. ${ }^{116}$ Expression of $\mathrm{Bcl}-\mathrm{x}_{\mathrm{L}}$ and $\mathrm{Mcl}-1$ potentially neutralizes all pro-apoptotic proteins. ${ }^{37}$ Viral blocking of the Mcl-1-specific inhibitor Noxa does not appear to be required to maintain host cell viability and $\mathrm{Mcl}-1$ may not be a significant survival signal in the cell types infected.

Recently a structure of the inhibitory peptide from cytomegalovirus Bcl-2 homolog, viral mitochondrial localized inhibitor of apoptosis (VMIA), in complex with Bax demonstrated a unique binding location distinct from the canonical BH3-biding site. Binding was mapped to inter-helical loop regions $\alpha 1-\alpha 2$, $\alpha 3-\alpha 4, \alpha 5-\alpha 6$ with residues contributed from $\alpha 9$ and the $\mathrm{C}$-terminus (equivalent to the lowermost loops in $\mathrm{Bcl}-\mathrm{x}_{\mathrm{L}}$ of Figure 2). Electrostatic interactions have a significant role in the interaction and the affinity was measured at $K_{d}$ of 22 nM. $^{117}$ In contrast to other Bcl-2 members that inhibit recruitment of Bax to mitochondria, vMIA recruits Bax to mitochondria independent of the Bax TM helix and does not rely on the $\alpha 1$ site. ${ }^{117}$

\section{Structural Plasticity of vBcl-2 Proteins Enables Additional Functionality}

Although a number of apoptosis-modulating viral Bcl-2 proteins target endogenous Bcl-2 family members, several recently determined structures point to additional biological activities that can be regulated by the $\mathrm{Bcl}-2$ fold. Vaccinia virus $\mathrm{N} 1 \mathrm{~L}$ is able to subvert Bcl-2-mediated host signaling. ${ }^{29,30}$ Further evidence suggests an additional role for N1L as a modulator of NF- $\kappa$ B signaling, ${ }^{118}$ an important mediator of the host innate immune response. $\mathrm{N} 1 \mathrm{~L}$ is thus endowed with dual functionality. To date, no other viral Bcl-2 protein has been shown to harbor both anti-apoptotic and NF- $\kappa \mathrm{B}$ modulatory activity. ${ }^{115,119}$ However, the ability to modulate NF- $\kappa B$ is not limited to N1L, two additional vaccinia virus factors $A 52$ and $\mathrm{B} 14^{120}$ have also been shown to adopt $\mathrm{Bcl}-2$ folds and act on the NF- $\kappa$ B pathway, but not the apoptotic pathway. Similar to 
N1L, both A52 and B14 do not harbor a transmembrane region and appear to be located in the cytosol. ${ }^{121}$ For the purpose of NF- $\kappa \mathrm{B}$ modulation, the loop-connecting helices 4 and 5 appears to be the site of activity, at least in the case of $\mathrm{A} 52^{120}$ and the hydrophobic $\mathrm{BH} 3$-binding groove that mediates $\mathrm{Bcl}-2$ family member interactions is in a closed conformation and is not involved in NF- $\kappa \mathrm{B}$ signaling. Mutagenesis data supports the alternative binding mode with the apoptotic and $\mathrm{NF}-\kappa \mathrm{B}$ functions on independent surfaces in N1L. ${ }^{122}$

Additional activities, other than modulation of $\mathrm{NF}-\kappa \mathrm{B}$ signaling, have been attributed to viral $\mathrm{Bcl}-2$ proteins. Work on vaccinia virus $\mathrm{K} 7$ revealed a $\mathrm{Bcl}$-2-like fold that was utilized to engage RNA helicases. ${ }^{123}$ The region on K7 that mediates helicase interactions was mapped using NMR to a shallow groove along the $\alpha 1$ helix, a region that corresponds to the N1L dimer interface. N1L dimerization was shown to be critical for inhibition of NF- $\kappa$ B signaling via a surface patch that covers the dimer interface and comprises the $\alpha 1$ and $\alpha 6$ helices. ${ }^{122}$ Non-groove-mediated functions of Bcl-2-like proteins are not limited to viral members of the family and structural evidence has emerged that Bax may also harbor an alternative interaction site for $\mathrm{BH} 3$-only proteins. ${ }^{57}$ Again, a surface region involving helices $\alpha 1$ and $\alpha 6$ was identified as the alternative site, suggesting that this region of $\mathrm{Bcl}-2$ proteins is available for functional interactions in both viral and mammalian family members. However, the structural data for the $\alpha 1 / \alpha 6$ interface is still rather weak for Bax.

\section{Comparison of Cellular with Viral Bcl-2 Family Members}

Although cellular and viral $\mathrm{Bcl}-2$ proteins adopt an identical fold, a number of differences hint at the different purposes for which these molecules evolved. Mammalian Bcl-2 members typically comprise eight alpha helices, a feature that is also observed for readily identifiable vBcl-2 proteins, such as $\mathrm{KsBcl}-2^{106}$ and BHRF1. ${ }^{107,108}$ However, more distant vBcl-2 proteins, such as M11L, ${ }^{31} \mathrm{~F}_{1} \mathrm{~L}^{27}$ and $\gamma \mathrm{HV} 68-\mathrm{vBcl}-2,{ }^{109}$ only contain seven alpha helices leading to a reduction in chain length required to form the $\mathrm{Bcl}-2$ fold. The sequences of mammalian multi-motif $\mathrm{Bcl}-2$ proteins vary in sequence length and are generally long due to the insertion of residues in the inter-helical loops, whereas their viral counterparts are typically shorter adopting a more economical compact fold lacking long inter-helical loops and in the case of the more distantly related $\mathrm{vBcl}-2$ homologs loss of $\alpha 7$. N1L encodes the entire $\mathrm{Bcl}-2$ fold within 115 residues, ${ }^{29,30}$ making it the member with the shortest primary sequence of the group, this contrasts with human $\mathrm{Bcl}-\mathrm{x}_{\mathrm{L}}$ that is 233 residues in length with a 50 -residue $\alpha 1-\alpha 2$ IDR loop. ${ }^{36}$ An exception is provided by vaccinia virus $\mathrm{F} 1 \mathrm{~L}$, which is encoded by 226 residues, including a $\sim 60$-residue $\mathrm{N}$-terminal extension. The $\mathrm{N}$-terminus of $\mathrm{F} 1 \mathrm{~L}$ has recently been identified to harbor additional biological activities, notably a caspases- 9 inhibitory function $^{124,125}$ as well as an unexpected inflammasome regulatory role. $^{126}$ This would establish $\mathrm{F} 1 \mathrm{~L}$ as the first $\mathrm{vBcl}-2$ to modulate inflammasome activity directly by binding NLRP1/ NALP1, in a manner reminiscent of $\mathrm{Bcl}-\mathrm{x}_{\mathrm{L}},{ }^{127}$ pointing toward an additional level of functional mimicry.

\section{Viral Bcl-2 Proteins Interact with BH3 Proteins with Relatively Low Affinity}

When comparing affinities of cellular $\mathrm{Bcl}-2$ proteins for their ligands with their viral homologs, a striking feature is the higher affinity of most cellular $\mathrm{Bcl}-2$ proteins compared with viral $\mathrm{Bcl}-2$ proteins. Furthermore, cellular pro-survival $\mathrm{Bcl}-2$ proteins tend to engage a much wider range of pro-apoptotic proteins ${ }^{9}$ than the viral counterparts. Whereas $\mathrm{Bcl}-\mathrm{x}_{\mathrm{L}}$ shows high affinity for all pro-apoptotic Bcl-2 members except Noxa, ${ }^{9}$ vaccinia virus $\mathrm{F} 1 \mathrm{~L}$ only binds $\mathrm{Bim}$, Bak and $\mathrm{Bax},{ }^{27}$ with affinities that are at least 20-fold lower compared with those of $\mathrm{Bcl}-\mathrm{x}_{\mathrm{L}}$. Additionally, two of the most promiscuous BH3-only proteins Bid and Puma, are only engaged by a limited number of viral $\mathrm{Bcl}-2$ proteins (Table 1). It is conceivable that the more selective ligand-binding profiles of a viral $\mathrm{Bcl}-2$ protein reflect the circumstance that only specific pro-apoptotic $\mathrm{Bcl}-2$ proteins require targeting during viral infection. The smaller number of ligands identified for certain vBcl-2 proteins might also be reflected in the changes within the canonical binding groove.

Although the core structural features of ligand engagement by viral $\mathrm{Bcl}-2$ members are conserved with their mammalian counterparts, some intriguing differences exist. The four key hydrophobic interactions with $\mathrm{BH} 3$ motifs are retained in all vBcl-2:BH3 motif structures, whereas the conspicuous salt bridge formed by an aspartic acid from the $\mathrm{BH} 3$ motif with an arginine residue from the accepting $\mathrm{Bcl}-2$ protein is not observed in the M11L:BakBH3 complex. This suggests that the salt bridge may not be a defining feature for vBcl-2-BH3 interactions as it seems for their cellular counterparts. M11L exhibits only minimal movement in the binding groove when binding a $\mathrm{BH} 3$ motif ligand, ${ }^{27}$ and displays high-affinity binding to a number of point mutants of Bak BH3 motif. In contrast, $\mathrm{Bcl}-\mathrm{x}_{\mathrm{L}}$ undergoes substantial changes in the binding groove (in the order of $9 \AA$ ) on $\mathrm{BH} 3$ motif binding, ${ }^{35,128}$ and appears to be unable to engage Bak $\mathrm{BH} 3$ point mutants. ${ }^{31}$ This suggests that $\mathrm{M} 11 \mathrm{~L}$ engagement of $\mathrm{BH} 3$ ligands is more robust, and not subject to subtle control mechanisms as required for the modulation of apoptosis signaling by endogenous cellular Bcl2 proteins. The reduced binding groove movement and robustness of ligand binding in the case of M11L could be a consequence of high-level optimization of M11L to engage only a small subset of pro-apoptotic Bcl-2 members.

\section{Concluding Remarks}

Bcl-2 proteins couple apoptotic stimuli with mitochondrial membrane permeabilization to initiate the caspase cascade. One of the most striking observations is that of the sequence and structural similarity between the multi-motif pro-apoptotic Bax and Bak and their pro-survival counterparts. This might imply that the mode of action of pro-survival and pro-apoptotic proteins are similar and that specific binding partners and interactions define their activity. Our understanding of this family is evolving, but current research is presenting a more unified mechanism with the canonical $\mathrm{BH} 3$-binding groove being the target in both pro-survival and pro-apoptotic proteins with high-affinity $\mathrm{BH} 3$ interactions in the former and moderated to low-affinity interaction observed for Bax and Bak. ${ }^{59-61}$ 
The thermodynamics of these processes remain poorly elucidated and converting the in vitro findings to a more physiological setting is required. Many questions also remain as to how Bax and Bak are inhibited by pro-survival proteins from the mammalian and viral Bcl-2 family and the molecular details of their mode of action at intracellular membrane surfaces are currently not available.

The role of viral $\mathrm{Bcl}-2$ proteins in apoptosis is probably more restricted than the mammalian Bcl-2 family, for instance no viral homolog of $\mathrm{Mcl}-1$ has yet been found, as they only have to keep host cell apoptosis in abeyance during replication. Conformational change in viral $\mathrm{Bcl}-2$ proteins is less important for their function with their primary requirement being optimized binding of their main targets, the initiators of apoptosis. What messages can we take from $\mathrm{Bcl}-2$ mimicry? In the most parsimonious case, viral $\mathrm{Bcl}-2$ proteins could simply antagonize the pan-pro-survival antagonist Bim preventing activation of Bax or Bak. The absence of observed specificity for other BH3-only proteins, particularly Bid/tBid and Puma, may suggest that subtle differences exist that govern activation of Bim expression compared with Bid and Puma. However, considering the absence of definitive expression studies that identify differential expression of potent $\mathrm{BH} 3$-only proteins during viral infections this remains speculative.

Determination of the structures and binding properties of $\mathrm{Bcl}-2$ family proteins has been a fruitful tool in delineating biological roles and the role of individual $\mathrm{Bcl}-2$ proteins and their viral counterparts. It has allowed predictions of possible functional importance of the members of the Bcl-2 family in regulating cell fate and a detailed molecular understanding is being put to use in designing inhibitors for members of this family to trigger tumor cell death by inactivation of pro-survival proteins. ${ }^{129,130}$ Development of antagonists against viral $\mathrm{Bcl}$ 2 proteins may prove a viable therapeutic approach to treating diseases etiologically linked to viral infection. For example, EBV expresses the pro-survival Bcl-2 homolog BHRF1, and chronic EBV infection is strongly associated with development of Burkitt's lymphoma. Constitutive BHRF1 expression ${ }^{131}$ has a prominent role in B-cell transformation ${ }^{102}$ and may contribute significantly to virus-associated lymphomagenesis, in addition to being associated with potent resistance to chemotherapy in mouse models of Burkitt's lymphoma. ${ }^{107}$ Viral Bcl-2 proteins only mimic select functions of mammalian proteins, thus presenting the tantalizing prospect of easier therapeutic amenability by limiting the number of potential offtarget effects. Given the recent advances in designing $\mathrm{BH} 3$ mimetics against mammalian pro-survival $\mathrm{Bcl}-2$ proteins to activate apoptosis for cancer therapies, ${ }^{129}$ such structurebased approaches against viral $\mathrm{Bcl}-2$ proteins may well be feasible, exploiting the fact that the Bcl-2 fold is put to work in a similar context but with a rather different purpose.

\section{Conflict of Interest}

The authors declare no conflict of interest.

Acknowledgements. Our research is supported by the Cancer Council Victoria (grant 575549, MGH), National Health and Medical Research Council of Australia (CDA fellowship 637372, MK and Project (APP1007918) to MK).
1. Strasser A, Cory S, Adams JM. Deciphering the rules of programmed cell death to improve therapy of cancer and other diseases. EMBO J 2011; 30: 3667-3683.

2. Hardwick JM, Soane L. Multiple functions of BCL-2 family proteins. Cold Spring Harb Perspect Biol 2013; 5: a008722.

3. Fuentes-Prior P, Salvesen GS. The protein structures that shape caspase activity, specificity, activation and inhibition. Biochem J 2004; 384: 201-232.

4. Kang R, Zeh HJ, Lotze MT, Tang D. The Beclin 1 network regulates autophagy and apoptosis. Cell Death Differ 2011; 18: 571-580.

5. Gump JM, Thorburn A. Autophagy and apoptosis: what is the connection? Trends Cell Biol 2011; 21: 387-392.

6. Denton D, Nicolson S, Kumar S. Cell death by autophagy: facts and apparent artefacts. Cell Death Differ 2012; 19: 87-95.

7. Youle RJ, Strasser A. The BCL-2 protein family: opposing activities that mediate cell death. Nat Rev Mol Cell Biol 2008; 9: 47-59.

8. Green DR, Kroemer G. The pathophysiology of mitochondrial cell death. Science 2004; 305: 626-629.

9. Chen L, Willis SN, Wei A, Smith BJ, Fletcher Jl, Hinds MG et al. Differential targeting of prosurvival Bcl-2 proteins by their $\mathrm{BH} 3$-only ligands allows complementary apoptotic function. Mol Cell 2005; 17: 393-403.

10. Kuwana T, Bouchier-Hayes L, Chipuk JE, Bonzon C, Sullivan BA, Green DR et al. $\mathrm{BH} 3$ domains of $\mathrm{BH} 3$-only proteins differentially regulate Bax-mediated mitochondrial membrane permeabilization both directly and indirectly. Mol Cell 2005; 17: 525-535.

11. Certo M, Del Gaizo Moore V, Nishino M, Wei G, Korsmeyer S, Armstrong SA et al. Mitochondria primed by death signals determine cellular addiction to antiapoptotic BCL-2 family members. Cancer Cell 2006; 9: 351-365.

12. Taylor JM, Barry M. Near death experiences: poxvirus regulation of apoptotic death. Virology 2006; 344: 139-150.

13. Wilson NS, Dixit V, Ashkenazi A. Death receptor signal transducers: nodes of coordination in immune signaling networks. Nat Immunol 2009; 10: 348-355.

14. Stennicke HR, Ryan CA, Salvesen GS. Reprieval from execution: the molecular basis of caspase inhibition. Trends Biochem Sci 2002; 27: 94-101.

15. Tait SW, Green DR. Mitochondria and cell death: outer membrane permeabilization and beyond. Nat Rev Mol Cell Biol 2010; 11: 621-632.

16. Sato T, Irie S, Krajewski S, Reed JC. Cloning and sequencing of a CDNA encoding the rat Bcl-2 protein. Gene 1994; 140: 291-292.

17. Yin XM, Oltvai ZN, Korsmeyer SJ. BH1 and $\mathrm{BH} 2$ domains of $\mathrm{Bcl}-2$ are required for inhibition of apoptosis and heterodimerization with Bax. Nature 1994; 369: 321-323.

18. Chittenden T, Flemington C, Houghton AB, Ebb RG, Gallo GJ, Elangovan B et al. A conserved domain in Bak, distinct from $\mathrm{BH} 1$ and $\mathrm{BH} 2$, mediates cell death and protein binding functions. EMBO J 1995; 14: 5589-5596.

19. Ke N, Godzik A, Reed JC. Bcl-B, a novel Bcl-2 family member that differentially binds and regulates Bax and Bak. J Biol Chem 2001; 276: 12481-12484.

20. Zha H, Aime-Sempe C, Sato T, Reed JC. Proapoptotic protein Bax heterodimerizes with $\mathrm{Bcl}-2$ and homodimerizes with Bax via a novel domain $(\mathrm{BH} 3)$ distinct from $\mathrm{BH} 1$ and $\mathrm{BH} 2$. J Biol Chem 1996; 271: 7440-7444.

21. Blaineau SV, Aouacheria A. BCL2DB: moving 'helix-bundled' BCL-2 family members to their database. Apoptosis 2009; 14: 923-925.

22. Lanave $C$, Santamaria M, Saccone C. Comparative genomics: the evolutionary history of the Bcl-2 family. Gene 2004; 333: 71-79.

23. Beverly LJ. Regulation of anti-apoptotic BCL2-proteins by non-canonical interactions: the next step forward or two steps back? J Cell Biochem 2012; 113: 3-12.

24. Huang DC, Strasser A. BH3-Only proteins-essential initiators of apoptotic cell death. Cell 2000; 103: 839-842.

25. Day CL, Smits C, Fan FC, Lee EF, Fairlie WD, Hinds MG. Structure of the BH3 domains from the p53-inducible BH3-only proteins Noxa and Puma in complex with Mcl-1. J Mol Biol 2008; 380: 958-971.

26. Adams JM, Cory S. The Bcl-2 protein family: arbiters of cell survival. Science 1998; 281 1322-1326.

27. Kvansakul M, Yang H, Fairlie WD, Czabotar PE, Fischer SF, Perugini MA et al. Vaccinia virus anti-apoptotic $\mathrm{F} 1 \mathrm{~L}$ is a novel Bcl-2-like domain-swapped dimer that binds a highly selective subset of BH3-containing death ligands. Cell Death Differ 2008; 15: 1564-1571.

28. Aouacheria A, Laval VR, Combet C, Hardwick JM. Evolution of Bcl-2 homology motifs: homology versus homoplasy. Trends Cell Biol 2012; 23: 103-111.

29. Cooray S, Bahar MW, Abrescia NG, McVey CE, Bartlett NW, Chen RA et al. Functional and structural studies of the vaccinia virus virulence factor $\mathrm{N} 1$ reveal a Bcl-2-like antiapoptotic protein. J Gen Virol 2007; 88: 1656-1666.

30. Aoyagi M, Zhai D, Jin C, Aleshin AE, Stec B, Reed JC et al. Vaccinia virus N1L protein resembles a B cell lymphoma-2 (Bcl-2) family protein. Protein Sci 2007; 16: 118-124.

31. Kvansakul M, van Delft MF, Lee EF, Gulbis JM, Fairlie WD, Huang DC et al. A structural viral mimic of prosurvival $\mathrm{Bcl}-2$ : a pivotal role for sequestering proapoptotic Bax and Bak. Mol Cell 2007; 25: 933-942.

32. Douglas AE, Corbett KD, Berger JM, McFadden G, Handel TM. Structure of M11L: A myxoma virus structural homolog of the apoptosis inhibitor, Bcl-2. Protein Sci 2007; 16 695-703.

33. Hinds MG, Day CL. Regulation of apoptosis: uncovering the binding determinants. Curr Opin Struct Biol 2005; 15: 690-699. 
34. Petros AM, Olejniczak ET, Fesik SW. Structural biology of the Bcl-2 family of proteins. Biochim Biophys Acta 2004; 1644: 83-94.

35. Sattler M, Liang H, Nettesheim D, Meadows RP, Harlan JE, Eberstadt M et al. Structure of Bcl-xL-Bak peptide complex: recognition between regulators of apoptosis. Science 1997; 275: 983-986.

36. Muchmore SW, Sattler M, Liang H, Meadows RP, Harlan JE, Yoon HS et al. X-ray and NMR structure of human Bcl-xL, an inhibitor of programmed cell death. Nature 1996; 381 335-341.

37. Rautureau GJ, Yabal M, Yang H, Huang DC, Kvansakul M, Hinds MG. The restricted binding repertoire of $\mathrm{Bcl}-\mathrm{B}$ leaves $\mathrm{Bim}$ as the universal $\mathrm{BH} 3$-only prosurvival $\mathrm{Bcl}-2$ protein antagonist. Cell Death Dis 2012; 3: e443.

38. Hinds MG, Smits C, Fredericks-Short R, Risk JM, Bailey M, Huang DC et al. $\mathrm{Bim}, \mathrm{Bad}$ and Bmf: intrinsically unstructured $\mathrm{BH} 3-$ only proteins that undergo a localized conformational change upon binding to prosurvival Bcl-2 targets. Cell Death Differ 2007 14: 128-136.

39. Rautureau GJ, Day CL, Hinds MG. Intrinsically disordered proteins in bcl-2 regulated apoptosis. International J Mol Sci 2010; 11: 1808-1824.

40. Yao Y, Bobkov AA, Plesniak LA, Marassi F. Mapping the interaction of pro-apoptotic tBID with pro-survival BCL-XL. Biochemistry 2009; 48: 8704-8711.

41. Hardwick JM, Chen YB, Jonas EA. Multipolar functions of BCL-2 proteins link energetics to apoptosis. Trends Cell Biol 2012; 22: 318-328.

42. Suzuki M, Youle RJ, Tjandra N. Structure of Bax: coregulation of dimer formation and intracellular localization. Cell 2000; 103: 645-654.

43. McDonnell JM, Fushman D, Milliman CL, Korsmeyer SJ, Cowburn D. Solution structure of the proapoptotic molecule BID: a structural basis for apoptotic agonists and antagonists. Cell 1999; 96: 625-634.

44. Chou JJ, Li H, Salvesen GS, Yuan J, Wagner G. Solution structure of BID, an intracellular amplifier of apoptotic signaling. Cell 1999; 96: 615-624.

45. Billen LP, Shamas-Din A, Andrews DW. Bid: a Bax-like BH3 protein. Oncogene 2008 27(Suppl 1): S93-104.

46. Lovell JF, Billen LP, Bindner S, Shamas-Din A, Fradin C, Leber B et al. Membrane binding by tBid initiates an ordered series of events culminating in membrane permeabilization by Bax. Cell 2008; 135: 1074-1084.

47. Hinds MG, Lackmann M, Skea GL, Harrison PJ, Huang DC, Day CL. The structure of $\mathrm{Bcl}-\mathrm{w}$ reveals a role for the $\mathrm{C}$-terminal residues in modulating biological activity. EMBO 2003; 22: 1497-1507.

48. Denisov AY, Madiraju MS, Chen G, Khadir A, Beauparlant P, Attardo G et al. Solution structure of human BCL-w: modulation of ligand binding by the C-terminal helix. J Bio Chem 2003; 278: 21124-21128.

49. Day CL, Chen L, Richardson SJ, Harrison PJ, Huang DC, Hinds MG. Solution structure of prosurvival $\mathrm{Mcl}-1$ and characterization of its binding by proapoptotic $\mathrm{BH} 3$-only ligands. J Biol Chem 2005; 280: 4738-4744.

50. Letai A, Bassik MC, Walensky LD, Sorcinelli MD, Weiler S, Korsmeyer SJ. Distinct BH3 domains either sensitize or activate mitochondrial apoptosis, serving as prototype cance therapeutics. Cancer Cell 2002; 2: 183-192.

51. Shamas-Din A, Kale J, Leber B, Andrews DW. Mechanisms of action of bcl-2 family proteins. Cold Spring Harb Perspect Biol 2013; 5: a008714.

52. Schinzel A, Kaufmann T, Borner C. Bcl-2 family members: intracellular targeting, membrane-insertion, and changes in subcellular localization. Biochim Biophys Acta 2004; 1644: 95-105.

53. Wilfling F, Weber A, Potthoff S, Vogtle FN, Meisinger C, Paschen SA et al. BH3-only proteins are tail-anchored in the outer mitochondrial membrane and can initiate the activation of Bax. Cell Death Differ 2012; 19: 1328-1336.

54. Echeverry N, Bachmann D, Ke F, Strasser A, Simon HU, Kaufmann T. Intracellular localization of the BCL-2 family member BOK and functional implications. Cell Death Differ 2013; 20: 785-799.

55. Todt F, Cakir Z, Reichenbach F, Youle RJ, Edlich F. The C-terminal helix of Bcl-x(L) mediates Bax retrotranslocation from the mitochondria. Cell Death Differ 2013; 20: 333-342.

56. Edlich F, Banerjee S, Suzuki M, Cleland MM, Arnoult D, Wang C et al. Bcl-x(L) retrotranslocates Bax from the mitochondria into the cytosol. Cell 2011; 145: 104-116.

57. Gavathiotis E, Suzuki M, Davis ML, Pitter K, Bird GH, Katz SG et al. BAX activation is initiated at a novel interaction site. Nature 2008; 455: 1076-1081.

58. Walensky LD, Gavathiotis E. BAX unleashed: the biochemical transformation of an inactive cytosolic monomer into a toxic mitochondrial pore. Trends Biochem Sci2011; 36 : 642-652.

59. Moldoveanu T, Grace CR, Llambi F, Nourse A, Fitzgerald P, Gehring K et al. BID-induced structural changes in BAK promote apoptosis. Nature Struct Mol Biol 2013; 20: 589-597.

60. Leshchiner ES, Braun CR, Bird GH, Walensky LD. Direct activation of full-length proapoptotic BAK. Proc Natl Acad Sci USA 2013; 110: 986-995.

61. Czabotar PE, Westphal D, Dewson G, Ma S, Hockings C, Fairlie WD et al. Bax crystal structures reveal how $\mathrm{BH} 3$ domains activate $\mathrm{Bax}$ and nucleate its oligomerization to induce apoptosis. Cell 2013; 152: 519-531.

62. Everett H, Barry M, Lee SF, Sun X, Graham K, Stone J et al. M11L: a novel mitochondrialocalized protein of myxoma virus that blocks apoptosis of infected leukocytes. J Exp Med 2000; 191: 1487-1498
63. Wasilenko ST, Stewart TL, Meyers AF, Barry M. Vaccinia virus encodes a previously uncharacterized mitochondrial-associated inhibitor of apoptosis. Proc Natl Acad Sci USA 2003: 100: 14345-14350.

64. Wei MC, Lindsten T, Mootha VK, Weiler S, Gross A, Ashiya M et al. tBID, a membranetargeted death ligand, oligomerizes BAK to release cytochrome c. Genes Dev 2000; 14 : 2060-2071.

65. Dewson G, Kluck RM. Mechanisms by which Bak and Bax permeabilise mitochondria during apoptosis. J Cell Sci 2009; 122: 2801-2808.

66. Sedlak TW, Oltvai ZN, Yang E, Wang K, Boise LH, Thompson CB et al. Multiple Bcl-2 family members demonstrate selective dimerizations with Bax. Proc Natl Acad Sci USA 1995; 92: 7834-7838.

67. Liu QA, Gehring K. Heterodimerization of BAK and MCL-1 activated by detergent micelles. J Biol Chem 2010; 285: 41202-41210.

68. Moldoveanu T, Liu Q, Tocili A, Watson M, Shore G, Gehring K. The X-ray structure of a BAK homodimer reveals an inhibitory zinc binding site. Mol Cell 2006; 24: $677-688$.

69. Hsu YT, Youle RJ. Nonionic detergents induce dimerization among members of the Bcl-2 family. J Biol Chem 1997; 272: 13829-13834.

70. Wallgren M, Lidman M, Pedersen A, Brannstrom K, Karlsson BG, Grobner G. Reconstitution of the anti-apoptotic bcl-2 protein into lipid membranes and biophysical evidence for its detergent-driven association with the pro-apoptotic bax protein. PLOS One 2013; 8: e61452.

71. Losonczi JA, Olejniczak ET, Betz SF, Harlan JE, Mack J, Fesik SW. NMR studies of the anti-apoptotic protein Bcl-xL in micelles. Biochemistry 2000; 39: 11024-11033.

72. Bogner C, Leber B, Andrews DW. Apoptosis: embedded in membranes. Curr Opin Cell Biol 2010; 22: 845-851.

73. Hsu YT, Youle RJ. Bax in murine thymus is a soluble monomeric protein that displays differential detergent-induced conformations. J Biol Chem 1998; 273: 10777-10783.

74. Griffiths GJ, Dubrez L, Morgan CP, Jones NA, Whitehouse J, Corfe BM et al. Cell damage-induced conformational changes of the pro-apoptotic protein Bak in vivo precede the onset of apoptosis. J Cell Biol 1999; 144: 903-914

75. O'Neill JW, Manion MK, Maguire B, Hockenbery DM. BCL-XL dimerization by three-dimensional domain swapping. J Mol Biol 2006; 356: 367-381.

76. Denisov AY, Sprules T, Fraser J, Kozlov G, Gehring K. Heat-induced dimerization of BCL-XL through alpha-helix swapping. Biochemistry 2007; 46: 734-740.

77. Feng Y, Lin Z, Shen X, Chen K, Jiang H, Liu D. Bcl-xL forms two distinct homodimers at non-ionic detergents: implications in the dimerization of $\mathrm{Bcl}-2$ family proteins. J Biochem 2008; 143: 243-252.

78. Follis AV, Chipuk JE, Fisher JC, Yun MK, Grace CR, Nourse A et al. PUMA binding induces partial unfolding within $\mathrm{BCL}-\mathrm{xL}$ to disrupt $\mathrm{p} 53$ binding and promote apoptosis. Nat Chem Biol 2013; 9: 163-168.

79. Oberstein A, Jeffrey PD, Shi Y. Crystal structure of the Bcl-XL-Beclin 1 peptide complex: Beclin 1 is a novel BH3-only protein. J Biol Chem 2007; 282: 13123-13132.

80. Lee EF, Dewson G, Smith BJ, Evangelista M, Pettikiriarachchi A, Dogovski C et al. Crystal structure of a BCL-W domain-swapped dimer: implications for the function of BCL-2 family proteins. Structure 2011; 19: 1467-1476.

81. Dewson G, Kratina T, Sim HW, Puthalakath H, Adams JM, Colman PM et al. To trigger apoptosis, Bak exposes its $\mathrm{BH} 3$ domain and homodimerizes via $\mathrm{BH}$ :groove interactions. $\mathrm{Mol}$ Cell 2008; 30: 369-380

82. Kushnareva Y, Andreyev AY, Kuwana T, Newmeyer DD. Bax activation initiates the assembly of a multimeric catalyst that facilitates Bax pore formation in mitochondrial outer membranes. PLoS Biol 2012; 10: e1001394.

83. Buck M. Crystallography: embracing conformational flexibility in proteins. Structure 2003 11: $735-736$

84. Otzen D. Protein-surfactant interactions: a tale of many states. Biochim Biophys Acta 2011; 1814: 562-591.

85. Lindsay J, Esposti MD, Gilmore AP. Bcl-2 proteins and mitochondria-specificity in membrane targeting for death. Biochim Biophys Acta 2011; 1813: 532-539.

86. Vogler M. BCL2A1: the underdog in the BCL2 family. Cell Death Differ 2011; 19: 67-74

87. Rautureau GJ, Day CL, Hinds MG. The structure of Boo/Diva reveals a divergent Bcl-2 protein. Proteins 2010; 78: 2181-2186.

88. Sborgi L, Barrera-Vilarmau S, Obregon $P$, de Alba $E$. Characterization of a novel interaction between Bcl-2 members Diva and Harakiri. PLoS One 2010; 5: e15575.

89. van de Kooij B, Rooswinkel RW, Kok F, Herrebout M, de Vries E, Paauwe M et al. Polyubiquitination and proteasomal turnover controls the anti-apoptotic activity of $\mathrm{Bcl}-\mathrm{B}$. Oncogene 2013; e-pub ahead of print 8 April 2013; doi:10.1038/onc.2013.99.

90. Galluzzi L, Kepp O, Trojel-Hansen C, Kroemer G. Non-apoptotic functions of apoptosisregulatory proteins. EMBO Rep 2012; 13: 322-330.

91. Petros AM, Gunasekera A, Xu N, Olejniczak ET, Fesik SW. Defining the p53 DNA-binding domain/Bcl-x(L)-binding interface using NMR. FEBS Lett 2004; 559: 171-174.

92. Ha JH, Shin JS, Yoon MK, Lee MS, He F, Bae KH et al. Dual-site interactions of p53 protein transactivation domain with anti-apoptotic Bcl-2 family proteins reveal a highly convergent mechanism of divergent p53 pathways. J Biol Chem 2013; 288: 7387-7398.

93. Chipuk JE, Kuwana T, Bouchier-Hayes L, Droin NM, Newmeyer DD, Schuler M et al. Direct activation of Bax by p53 mediates mitochondrial membrane permeabilization and apoptosis. Science 2004; 303: 1010-1014. 
94. Autret A, Martin SJ. Emerging role for members of the Bcl-2 family in mitochondrial morphogenesis. Mol Cell 2009; 36: 355-363.

95. Perciavalle RM, Stewart DP, Koss B, Lynch J, Milasta S, Bathina M et al. Anti-apoptotic MCL-1 localizes to the mitochondrial matrix and couples mitochondrial fusion to respiration. Nat Cell Biol 2012; 14: 575-583.

96. Michels J, Kepp O, Senovilla L, Lissa D, Castedo M, Kroemer G et al. Functions of BCL-X L at the interface between cell death and metabolism. Int J Cell Biol 2013; 2013: 705294.

97. Cuconati A, White $E$. Viral homologs of BCL-2: role of apoptosis in the regulation of virus infection. Genes Dev 2002; 16: 2465-24678.

98. Pilder S, Logan J, Shenk T. Deletion of the gene encoding the adenovirus 5 early region 1b 21 000-molecular-weight polypeptide leads to degradation of viral and host cell DNA. $J$ Virol 1984; 52: 664-671.

99. Jurak I, Schumacher U, Simic H, Voigt S, Brune W. Murine cytomegalovirus m38.5 protein inhibits Bax-mediated cell death. J Virol 2008; 82: 4812-4822.

100. Brune W, Nevels M, Shenk T. Murine cytomegalovirus $m 41$ open reading frame encodes a Golgi-localized antiapoptotic protein. J Virol 2003; 77: 11633-11643.

101. Fleming P, Kvansakul M, Voigt V, Kile BT, Kluck RM, Huang DC et al. MCMV-mediated inhibition of the pro-apoptotic Bak protein is required for optimal in vivo replication. PLoS Pathog 2013; 9: e1003192.

102. Altmann M, Hammerschmidt W. Epstein-Barr virus provides a new paradigm: a requirement for the immediate inhibition of apoptosis. PLoS biol 2005; 3: e404.

103. Gangappa S, van Dyk LF, Jewett TJ, Speck SH. Virgin HWt. Identification of the in vivo role of a viral bcl-2. J Exp Med 2002; 195: 931-940.

104. Macen JL, Graham KA, Lee SF, Schreiber M, Boshkov LK, McFadden G. Expression of the myxoma virus tumor necrosis factor receptor homologue and $\mathrm{M} 11 \mathrm{~L}$ genes is required to prevent virus-induced apoptosis in infected rabbit T lymphocytes. Virology 1996; 218: 232-237.

105. White E, Sabbatini P, Debbas M, Wold WS, Kusher DI, Gooding LR. The 19-kilodalton adenovirus E1B transforming protein inhibits programmed cell death and prevents cytolysis by tumor necrosis factor alpha. Mol Cell Biol 1992; 12: 2570-2580.

106. Huang Q, Petros AM, Virgin HW, Fesik SW, Olejniczak ET. Solution structure of a Bcl-2 homolog from Kaposi sarcoma virus. Proc Natl Acad Sci USA 2002; 99 3428-3433.

107. Kvansakul M, Wei AH, Fletcher Jl, Willis SN, Chen L, Roberts AW et al. Structural basis for apoptosis inhibition by Epstein-Barr virus BHRF1. PLoS Pathog 2010; 6: e1001236.

108. Huang $Q$, Petros AM, Virgin HW, Fesik SW, Olejniczak ET. Solution structure of the BHRF1 protein from Epstein-Barr virus, a homolog of human Bcl-2. J Mol Biol 2003; 332 1123-1130.

109. Loh J, Huang Q, Petros AM, Nettesheim D, van Dyk LF, Labrada L et al. A surface groove essential for viral Bcl-2 function during chronic infection in vivo. PLoS Pathog 2005 1: e10.

110. Nava VE, Cheng EH, Veliuona M, Zou S, Clem RJ, Mayer ML et al. Herpesvirus saimiri encodes a functional homolog of the human bcl-2 oncogene. J Virol 1997; 71: 4118-4122.

111. Banadyga L, Gerig J, Stewart T, Barry M. Fowlpox virus encodes a Bcl-2 homologue that protects cells from apoptotic death through interaction with the proapoptotic protein Bak. $J$ Virol 2007; 81: 11032-11045.

112. Tulman ER, Afonso CL, Lu Z, Zsak L, Kutish GF, Rock DL. The genome of canarypox virus. J Virol 2004; 78: 353-366.

113. Aouacheria A, Banyai M, Rigal D, Schmidt CJ, Gillet G. Characterization of vnr-13, the first alphaherpesvirus gene of the bcl-2 family. Virology 2003; 316: 256-266.

114. Bartlett N, Symons JA, Tscharke DC, Smith GL. The vaccinia virus N1L protein is an intracellular homodimer that promotes virulence. J Gen Virol 2002; 83: 1965-1976.

115. Okamoto T, Campbell S, Mehta N, Thibault J, Colman PM, Barry M et al. Sheeppox virus SPPV14 encodes a Bcl-2-like cell death inhibitor that counters a distinct set of mammalian pro-apoptotic proteins. J Virol 2012; 86: 11501-11511.

116. Westphal D, Ledgerwood EC, Tyndall JD, Hibma MH, Ueda N, Fleming SB et al. The orf virus inhibitor of apoptosis functions in a Bcl-2-like manner, binding and neutralizing a set of BH3-only proteins and active Bax. Apoptosis 2009; 14: 1317-1330.
117. Ma J, Edlich F, Bermejo GA, Norris KL, Youle RJ, Tjandra N. Structural mechanism of Bax inhibition by cytomegalovirus protein vMIA. Proc Natl Acad Sci USA 2012; 109: 20901-20906.

118. DiPerna G, Stack J, Bowie AG, Boyd A, Kotwal G, Zhang Z et al. Poxvirus protein N1L targets the I-kappaB kinase complex, inhibits signaling to NF-kappaB by the tumor necrosis factor superfamily of receptors, and inhibits NF-kappaB and IRF3 signaling by toll-like receptors. J Biol Chem 2004; 279: 36570-36578.

119. Banadyga L, Lam SC, Okamoto T, Kvansakul M, Huang DC, Barry M. Deerpox virus encodes an inhibitor of apoptosis that regulates Bak and Bax. J Virol 2011; 85: 1922-1934.

120. Graham SC, Bahar MW, Cooray S, Chen RA, Whalen DM, Abrescia NG et al. Vaccinia virus proteins $\mathrm{A} 52$ and $\mathrm{B} 14$ share a Bcl-2-like fold but have evolved to inhibit NF-kappaB rather than apoptosis. PLoS Pathog 2008; 4: e1000128.

121. Chen RA, Jacobs N, Smith GL. Vaccinia virus strain Western Reserve protein B14 is an intracellular virulence factor. J Gen Virol 2006; 87: 1451-1458.

122. de Motes CM, Cooray S, Ren H, Almeida GMF, McGourty K, Bahar MW et al. Inhibition of apoptosis and NF-kB activation by Vaccinia protein $\mathrm{N} 1$ occur via distinct binding surfaces and make different contributions to virulence. PLoS Pathog 2011; 7: e1002430.

123. Kalverda AP, Thompson GS, Vogel A, Schroder M, Bowie AG, Khan AR et al. Poxvirus $\mathrm{K} 7$ protein adopts a $\mathrm{Bcl}-2$ fold: biochemical mapping of its interactions with human DEAD box RNA helicase DDX3. J Mol Biol 2009; 385: 843-853.

124. Yu E, Zhai D, Jin C, Gerlic M, Reed JC, Liddington R. Structural determinants of caspase-9 inhibition by the vaccinia virus protein, F1L. J Biol Chem 2011; 286 30748-30758.

125. Zhai $\mathrm{D}$, Yu E, Jin C, Welsh $\mathrm{K}$, Shiau $\mathrm{CW}$, Chen $\mathrm{L}$ et al. Vaccinia virus protein $\mathrm{F} 1 \mathrm{~L}$ is a caspase-9 inhibitor. J Biol Chem 2010; 285: 5569-5580.

126. Gerlic M, Faustin B, Postigo A, Yu EC, Proell M, Gombosuren N et al. Vaccinia virus F1L protein promotes virulence by inhibiting inflammasome activation. Proc Natl Acad Sci USA 2013; 110: 7808-7813.

127. Bruey JM, Bruey-Sedano N, Luciano F, Zhai D, Balpai R, Xu C et al. Bcl-2 and Bcl-XL regulate proinflammatory caspase-1 activation by interaction with NALP1. Cell 2007; 129 : $45-56$.

128. Liu X, Dai S, Zhu Y, Marrack $P$, Kappler JW. The structure of a Bcl-xL/Bim fragment complex: implications for Bim function. Immunity 2003; 19: 341-352.

129. Lessene G, Czabotar PE, Colman PM. BCL-2 family antagonists for cancer therapy. Nat Rev. Drug Discov 2008; 7: 989-1000.

130. Roberts AW, Seymour JF, Brown JR, Wierda WG, Kipps TJ, Khaw SL et al. Substantial susceptibility of chronic lymphocytic leukemia to BCL2 inhibition: results of a phase I study of navitoclax in patients with relapsed or refractory disease. J Clin Oncol 2012; 30: 488-496.

131. Kelly GL, Long HM, Stylianou J, Thomas WA, Leese A, Bell Al et al. An Epstein-Barr virus anti-apoptotic protein constitutively expressed in transformed cells and implicated in burkitt lymphomagenesis: the Wp/BHRF1 link. PLoS Pathog 2009; 5: e1000341.

132. Flanagan $\mathrm{AM}$, Letai $\mathrm{A}$. $\mathrm{BH} 3$ domains define selective inhibitory interactions with $\mathrm{BHRF}-1$ and KSHV BCL-2. Cell Death Differ 2008; 15: 580-588.

133. Willis SN, Chen L, Dewson G, Wei A, Naik E, Fletcher Jl et al. Proapoptotic Bak is sequestered by $\mathrm{Mcl}-1$ and $\mathrm{Bcl}-\mathrm{xL}$, but not $\mathrm{Bcl}-2$, until displaced by $\mathrm{BH}$-only proteins. Genes Dev 2005; 19: 1294-1305.

134. Fletcher JI, Meusburger S, Hawkins CJ, Riglar DT, Lee EF, Fairlie WD et al. Apoptosis is triggered when prosurvival Bcl-2 proteins cannot restrain Bax. Proc Natl Acad Sci USA 2008; 105: 18081-18087.

135. Smits $C$, Czabotar PE, Hinds MG, Day CL. Structural plasticity underpins promiscuous binding of the prosurvival protein A1. Structure 2008; 16: 818-829.

(c) (i) $\odot$ Cell Death and Disease is an open-access journal published by Nature Publishing Group. This work is licensed under a Creative Commons Attribution-NonCommercialNoDerivs 3.0 Unported License. To view a copy of this license, visit http://creativecommons.org/licenses/by-nc-nd/3.0/ 